\title{
Thrips species (Insecta: Thysanoptera) associated with flowers in a restinga fragment in northeastern Brazil
}

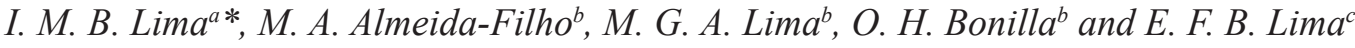 \\ ${ }^{a}$ Universidade Federal do Ceará - UFC, Avenida Mister Hull, s/n, Campus do Pici, CEP 60455-760, Fortaleza, CE, Brasil \\ bLaboratório de Interação Inseto-Planta - LABIIP, Universidade Estadual do Ceará - UECE, Avenida Dr. Silas Munguba, \\ 1700, Campus do Itaperi, CEP 60740-000, Fortaleza, CE, Brasil \\ 'Universidade Federal do Piauí - UFPI, BR 343, Km 3,5, Campus Amílcar Ferreira Sobral, CEP 64800-000, Floriano, PI, Brasil \\ *e-mail: isabellymbl@hotmail.com
}

Received: September 9, 2016 - Accepted: August 30, 2017 - Distributed: February 28, 2019

(With 2 figures)

\begin{abstract}
With the growing volume of research involving Thysanoptera in Brazil, studies were carried out to improve our understanding of the diversity of thrips in areas where the fauna has historically been neglected. Accordingly, we recorded the diversity of thrips (Insecta: Thysanoptera) associated with a restinga fragment located on the campus of the State University of Ceará (UECE), Fortaleza, Ceará state, and computed the estimated richness and diversity indices. Samples were collected from 2011 through 2013 from flowers of 86 plant species. The material was taken to the Laboratory of Insect-Plant Interaction, where thrips were screened under stereomicroscope. We collected 456 adults and 58 immatures, representing 14 species, in addition to one unidentified species of Treherniella. Microcephalothrips abdominalis was found on a large number of host plants, and Frankliniella insularis was the most common species. About two-thirds of the total richness of thrips species was associated with three plant families (Amaranthaceae, Caesalpiniaceae and Poaceae); six thrips species were each associated with only one plant species. The richness of the species collected was close to that estimated by Bootstrap and Jackknife 1 analysis. The Shannon-Wiener (H') and Simpson (D) diversity indexes were 1,7607 and 0.7769, respectively. Although the species are common, 46 new associations between plant species and thrips were established, 13 of which are true host associations, which demonstrates the importance of coastal vegetation in maintaining populations of thrips.
\end{abstract}

Keywords: insects, host plants, coastal forest.

\section{Espécies de tripes (Insecta: Thysanoptera) associadas a flores em um fragmento de restinga no nordeste brasileiro}

\section{Resumo}

Com o crescente volume de pesquisas envolvendo Thysanoptera no Brasil, estudos foram promovidos para melhorar nosso entendimento da diversidade de tripes em área onde a fauna tem sido historicamente negligenciada. Dessa maneira, neste trabalho registramos a diversidade de tripes (Insecta: Thysanoptera) associada a um fragmento de restinga localizado no Campus da Universidade Estadual do Ceará (UECE), município de Fortaleza, estado do Ceará, e computamos a riqueza estimada de espécies e índices de diversidade. Foram realizadas coletas entre os anos de 2011 a 2013 em flores de 86 espécies vegetais. O material foi levado ao Laboratório de Interação Inseto-Planta (UECE) onde os tripes foram triados manualmente sob estereomicroscópio. Foram coletados 456 tripes adultos e 58 imaturos, representando 14 espécies, além de uma espécie não identificada de Treherniella. Microcephalothrips abdominalis foi encontrado em um maior número de plantas hospedeiras, e Frankliniella insularis foi a espécie mais frequente. Cerca de dois-terços da riqueza total de espécies de tripés está associada a três famílias botânicas (Amarnthaceae, Caesalpiniaceae e Poaceae); seis espécies de tripes foram encontradas em associação com somente uma espécie vegetal. A riqueza de espécies coletada foi próxima daquela estimada pelas análises Bootstrap e Jackknife 1. Os índices de diversidade de Shannon-Wiener (H') e Simpson (D) foram 1.7607 e 0,7769, respectivamente. Embora as espécies identificadas sejam comuns, 46 novas associações entre tripes e espécies vegetais foram constatadas, 13 das quais são associações hospedeiras verdadeiras, o que demonstra a importância da vegetação costeira na manutenção das populações de tripes.

Palavras-chave: insetos, plantas hospedeiras, mata litorânea. 


\section{Introduction}

The world fauna of Thysanopotera includes approximately 6,000 species distributed in 800 genera (ThripsWiki, 2017). In the Neotropical Region, thrips have been relatively little studied, although this region has an enormous diversity of topography and flora, including mountains, large deserts and extensive tropical forests. According to Mound (2013), most thrips species recorded in South America are from Brazil.

According to Monteiro and Mound (2012), six of the eight families of thrips are found in Brazil (Uzelothripidae, Heterothripidae Merothripidae, Aeolothripidae, Thripidae and Phlaeothripidae) with a total of 576 species (Monteiro and Lima, 2011; Lima, 2017). However, thrips have been recorded from only a small part of the Brazilian territory, especially the states of São Paulo, Rio de Janeiro, Santa Catarina and Rio Grande do Sul (Monteiro and Mound, 2012; Lima, 2017). Santa Catarina and São Paulo alone account for more than half of the thrips fauna recorded in Brazil, mainly from studies carried out by Fritz Plaumann and J. Douglas Hood in the 1940s and 1950s (Monteiro, 2002; Lima, 2017).

In contrast, in northeastern Brazil, only a few studies of the Thysanoptera fauna have been conducted, mostly regarding cultivated plants, such as mango (Mangifera indica L.) in the state of Pernambuco (Oliveira et al., 2011); watermelon (Citrullus lanatus ((Thunb.) Matsum. \& Nakai) in Rio Grande do Norte (Costa et al., 2015) and native and cultivated Fabaceae in Piauí and Maranhão (Lima et al., 2013a, b). In Ceará, there are also a few records of thrips species, mainly associated with zucchini squash (Curcubita pepo L.), onion (Allium cepa L.) and tomato (Solanum lycopersicum L.) (Lima et al., 2011).

It is essential to carry out studies involving the interaction of thrips and their hosts in their native areas, especially in neglected regions, in order to extend our knowledge of the Brazilian thrips fauna and the position that these insects occupy in different ecosystems. One of these native areas is the coastal forest habitat known as restinga, which exists in fragments that are severely threatened by human occupation along the entire Brazilian coast. So far, no thrips surveys in this type of environment have been conducted in the country, in contrast with the situation of other insect orders, such as Lepidoptera, Coleoptera and Diptera (Flinte et al., 2006; Monteiro et al., 2007; Silveira et al., 2008; Gostinski et al., 2016). The lack of such information impedes the development of conservation and management strategies for these and other organisms.

This study assessed the diversity of thrips in restinga remnants in the state of Ceará, Brazil, as an attempt to foster research on thrips in the Brazilian Northeast. Diversity was evaluated by means of diversity indices and a species-accumulation curve.

\section{Material and Methods}

\subsection{Fieldwork}

The collections were performed at points with flowering plants in a coastal forest (restinga) fragment in areas belonging to the Universidade Estadual do Ceará (UECE), Campus of Itaperi, Fortaleza, Ceará, Brazil (Figure 1). The UECE Itaperi Campus is located in the municipality of Fortaleza $\left(03^{\circ} 47^{\prime} 45^{\prime}\right.$ 'S, $038^{\circ} 33^{\prime} 10^{\prime}$ 'W, $38.4 \mathrm{~m}$ a.s.1.) and covers an area of 104 ha on the coastal plain, about $8 \mathrm{Km}$ from the Ocean, with typical coastal vegetation (Esteves and Lacerda, 2000; IBGE, 2012), although heavily human-impacted (Brandão, 2003). This remnant is composed mainly $(70 \%)$ of plants with a mean height of 6 meters that lose more than $30 \%$ of their leaves during the dry season. Aside from this, the vegetation near the campus buildings is herbaceous and shrubby, and remains green almost year-round.

A total of 86 plant species belonging to 34 families (Table 1) were sampled for thrips. Surveys were performed once a month in April, May, June and July 2011; February through August 2012; and February through August 2013. The plants were collected randomly, depending on the availability of flowers and inflorescences, typical habitats of common thrips (Lewis, 1973, 1997). Sampling was carried out between 7:00 and 9:00, and approximately 5 flowers from each species were placed in individual plastic bags and taken to the Laboratory of Insect-Plant Interaction, where the insects were screened under a stereomicroscope and the plant species were identified. The insects were stored in microtubes with AGA (10 parts of ethanol $60 \%$, one part glycerin and one part glacial acetic acid) for preservation.

\subsection{Identification}

Adult thrips were mounted on permanent microscope slides and identified based on Mound and Marullo (1996). Plants were identified by comparison with herbarium specimens and using specialized literature (Bridson and Forman, 1998; Esteves and Lacerda, 2000; Brito et al., 2006; Moro et al., 2011). Vouchers of the thrips are deposited in the collection of the Laboratory of Insect-Plant Interaction (UECE).

\subsection{Statistical analysis}

A species-accumulation curve and species-richness estimators were calculated using the software EstimateS 9.1 (Colwell, 2013) in order to evaluate the sampling methods and to calculate the estimated richness of thrips in the particular restinga fragment. Only nonparametric incidence-based estimators (ICE, Chao 2, Jackknife 1, Jackknife 2 and Bootstrap) (Gotelli and Colwell, 2001) were computed, using the classic model with $95 \%$ confidence intervals and 1000 randomizations. Also, the diversity indices of Shannon-Wiener (H') and Simpson (D) were calculated using the software DiVes 3.0.7 (Rodrigues, 2015). The Shannon-Wiener index was also calculated using data from plant families with higher richness of associated thrips to compare possible differences in diversity. 


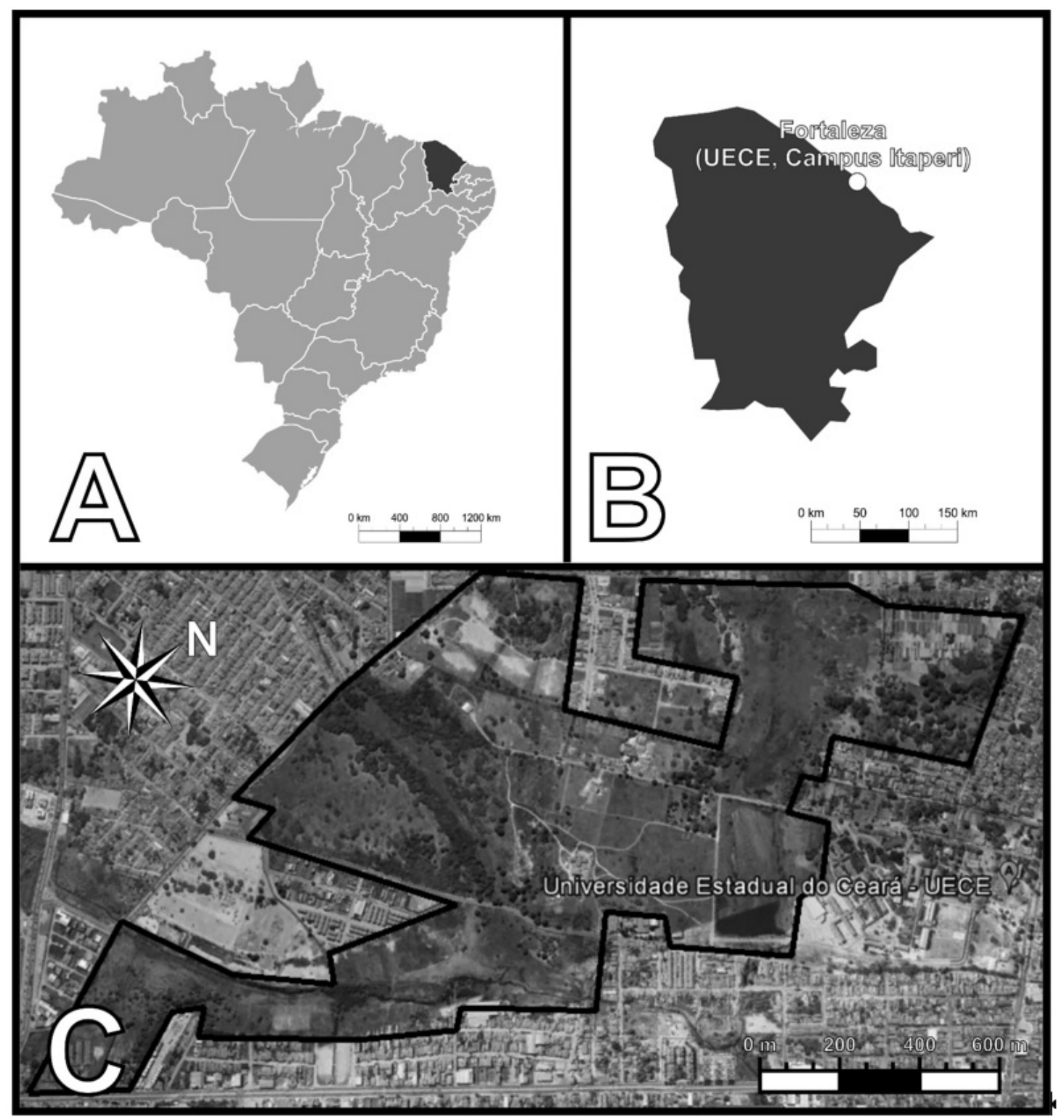

Figure 1. Location of the remnants of restinga vegetation in Fortaleza, Ceará, Brazil (UECE - Itaperi Campus) (0347'45"S, 038 33’10”W, 38.4 m a.s.1.). (A) State of Ceará on Brazil's map; (B) Location of the municipality of Fortaleza, State of Ceará; (C) Sampling area in Universidade Estadual do Ceará, Campus Itaperi, Fortaleza, CE, Brazil.

\section{Results}

A total of 456 thrips specimens belonging to 14 species were found in association with the coastal vegetation. Fifty-eight immatures (13 Tubulifera and 45 Terebrantia) were also found. The insects were associated with 36 of the 86 plant species sampled (Table 2). One probable new species of Treherniella was collected, and 46 new associations between thrips species and plants were established (Table 2), of which 13 are true host associations based on larvae collection (Table 2).

The accumulation curve did not reach an asymptote. The results obtained with the Chao 2,
ICE and Jackknife 2 estimators indicate that at least ten more species may exist in the area. On the other hand, the resulting estimates of Bootstrap (17.88) and Jackknife 1 (22.58) are closer to the number of species effectively surveyed (Figure 2).

The Shannon-Wiener (H') and Simpson (D) indices for the sampled area were 1,7607 and 0.7769 respectively (Table 3). Thrips richness and abundance were concentrated in three plant families, Amaranthaceae, Caesalpiniaceae and Poaceae. Plant species of the three families harbored two-thirds of the thrips species collected, and about half of the thrips abundance sampled (Tables 1 and 2). 
Table 1. Plant species surveyed during thrips collections in restinga fragment on the campus of State University of Ceará, Brazil.

\begin{tabular}{|c|c|}
\hline Family & $\begin{array}{l}\text { Species } \\
\end{array}$ \\
\hline Acanthaceae & Thunbergia erecta (Benth.) T. Anderson \\
\hline Anacardiaceae & Anacardium occidentale L. \\
\hline Amaranthaceae & Alternanthera brasiliana (L.) Kuntze \\
\hline & Amaranthus deflexus L. \\
\hline & Celosia cristata $\mathrm{L}$ \\
\hline \multirow{4}{*}{ Apocynaceae } & Froelichia interrputa (L.) Moq. \\
\hline & Allamanda cathartica $\mathrm{L}$. \\
\hline & Catharantus roseus L. \\
\hline & Nerium oleander L. \\
\hline \multirow[t]{7}{*}{ Asteraceae } & Aspilia cearensis J.U. Santos \\
\hline & Bidens bipinnata L. \\
\hline & Blainvillea rhomboidea Cass. \\
\hline & Centratherum punctatum Cass. \\
\hline & Emilia coccinea (Sims) G. Don \\
\hline & Helianthus annuus L. \\
\hline & Tithonia diversifolia (Hemsl.) A. Gray \\
\hline Bixaceae & Bixa orellana L. \\
\hline Bombacaceae & Chorisia glaziovii (Kuntze) E. Santos \\
\hline \multirow[t]{2}{*}{ Boraginaceae } & Cordia leucocephala Moric \\
\hline & Heliotropium indicum L. \\
\hline Cactaceae & Opuntia cochenillifera (L.) Mill \\
\hline \multirow[t]{11}{*}{ Caesalpiniaceae } & Aeschynomene viscidula Michx \\
\hline & Caesalpinia ferrea Martins \\
\hline & Caesalpinia leiostachya \\
\hline & Cicer arietinum L. \\
\hline & Clitoria fairchildiana R.A. Howard \\
\hline & Clitoria ternatea $\mathrm{L}$. \\
\hline & Crotalaria incana L. \\
\hline & Macroptiliem lathyroides L. \\
\hline & Mimosa sp. \\
\hline & Senna obtusifolia (L.) \\
\hline & Senna sp. \\
\hline Capparaceae & Cleome affinis D.C. \\
\hline Commelinaceae & Commelina benghalensis L. \\
\hline \multirow[t]{4}{*}{ Convolvulaceae } & Evolvulus anagalloides Meisn. \\
\hline & Ipomea asarifolia (Desr.) \\
\hline & Ipomoea pes-caprae (L.) R.Br. \\
\hline & Merremia aegyptia (L.) Urb. \\
\hline \multirow[t]{2}{*}{ Cucurbitaceae } & Momordica charantia L. \\
\hline & Cucurbita moschata Duchesne ex Poir \\
\hline \multirow[t]{3}{*}{ Cyperaceae } & Cyperus esculentus \\
\hline & Cyperus ferax (L.) Rich \\
\hline & Cyperus ligularis L. \\
\hline \multirow[t]{3}{*}{ Euphorbiaceae } & Chamaesyce hyssopifolia $\mathrm{L}$. \\
\hline & Croton Lobatus L. \\
\hline & Euphorbia hyssopifolia L. \\
\hline \multirow{3}{*}{$\begin{array}{l}\text { Heliconiaceae } \\
\text { Lamiaceae }\end{array}$} & Heliconia sp. \\
\hline & Hyptis simulans Epling \\
\hline & Mesosphaerum suaveolens (L.) Kuntze \\
\hline \multirow{9}{*}{$\begin{array}{l}\text { Malpigiaceae } \\
\text { Malvaceae }\end{array}$} & Byrsonima crassifolia (L.) Rich \\
\hline & Guazama ulmifolia Lam. \\
\hline & Hibiscus rosa-sinensis L. \\
\hline & Pavonia cancellata (L.) Cav. \\
\hline & Sida cordifolia L. \\
\hline & Sida galheirensis Ulbr \\
\hline & Sida micrantha A. ST. -Hill \\
\hline & Sidastrum micranthum A. ST. -Hil \\
\hline & Waltheria indica $\mathrm{L}$. \\
\hline
\end{tabular}


Table 1. Continued...

\begin{tabular}{|c|c|}
\hline Family & Species \\
\hline Nyctaginaceae & Boerhavia diffusa $\mathrm{L}$ \\
\hline Oxalidaceae & Oxalis divaricata Mart. ex Zucc \\
\hline Plantaginaceae & $\begin{array}{c}\text { Angelonia campestris Nees \& Mart } \\
\text { Scoparia dulcis L. }\end{array}$ \\
\hline \multirow[t]{9}{*}{ Poaceae } & Cenchrus echinatus $L$. \\
\hline & Cynodon dactylon (L.) Pers. \\
\hline & Eleusine indica (L.) Gaertn \\
\hline & Melinis repens (Wild.) Zizka \\
\hline & Panicum maximum Jacq. \\
\hline & Paspalum plicatulum Michx \\
\hline & Paspalum urvillei Steud. \\
\hline & Pennisetum purpureum Schum \\
\hline & Setaria parviflora (Poir) Kerguelen \\
\hline Rosaceae & Cydonia oblonga Mill. \\
\hline Rubiaceae & Richardia grandiflora Steud \\
\hline & Spermacoce verticillata $\mathrm{L}$. \\
\hline Rutaceae & Citrus sinensis \\
\hline Saxifragaceae & Philadelphus caucasicus Koehne \\
\hline Solanaceae & Solanum asperum L. C. Rich. \\
\hline Sterculiaceae & Guazuma ulmifolia Lamark \\
\hline Turneraceae & Turnera subulata $\mathrm{Sm}$. \\
\hline Typhaceae & Thypa angustifolia $\mathrm{L}$. \\
\hline Verbenaceae & Clerodendrum splendens $G$. Don. \\
\hline & Duranta repens L. "aurea” \\
\hline & Lantana camara $\mathrm{L}$ \\
\hline & Priva bahiensis A. DC. \\
\hline & Stachytarpheta coccinea Schauer \\
\hline Zingiberaceae & Alpinia purpurata K. Schum \\
\hline
\end{tabular}

Table 2. Thrips species of thrips and their respective hosts in fragment of restinga vegetation in the municipality of Fortaleza, Ceará, Brazil.

\begin{tabular}{|c|c|c|c|}
\hline \multirow[t]{2}{*}{ Thrips species } & \multirow[t]{2}{*}{ Associated Plant species } & \multicolumn{2}{|c|}{ Thrips individuals } \\
\hline & & $\bar{o}$ & 웅 \\
\hline \multirow[t]{2}{*}{ Arorathrips mexicanus (Crawford) } & Eleusine indica & - & 1 \\
\hline & Waltheria indica* & - & 1 \\
\hline \multirow[t]{3}{*}{ Frankliniella brevicaulis (Hood) } & Bixa orellana & 1 & 4 \\
\hline & Celosia cristata* & - & 6 \\
\hline & Thunbergia erecta* & - & 6 \\
\hline \multirow[t]{4}{*}{ Frankliniella gardeniae (Moulton) } & Aspilia cearensis* & - & 1 \\
\hline & Cicer arietinum* & - & 1 \\
\hline & Crotalaria incana & - & 8 \\
\hline & Guazuma ulmifolia* & - & 1 \\
\hline Frankliniella gemina (Bagnall) & Cicer arietinum* & - & 6 \\
\hline \multirow[t]{7}{*}{ Frankliniella insularis (Franklin) } & Bixa orellana ${ }^{+}$ & 10 & 26 \\
\hline & Caesalpinia leiostachya*+ & 3 & 15 \\
\hline & Centratherum punctatum* & - & 3 \\
\hline & Clitoria fairchildiana*+ & 22 & 65 \\
\hline & Clitoria ternatea* & - & 2 \\
\hline & Crotalaria incana & - & 1 \\
\hline & Mesospherum suaveolens* & - & 1 \\
\hline
\end{tabular}

*New records of association with plant species in Brazil; +Host-associations based on larvae collection. 
Table 2. Continued...

\begin{tabular}{|c|c|c|c|}
\hline Thrips species & Associated Plant species & \multicolumn{2}{|c|}{ Thrips individuals } \\
\hline & Momordica charantia & - & 7 \\
\hline & Pennisetum purpureum* & - & 2 \\
\hline & Senna sp. & - & 1 \\
\hline & Thunbergia erecta* & - & 1 \\
\hline \multirow[t]{9}{*}{ Frankliniella schultzei (Trybom) } & Allamanda cathartica* & - & 1 \\
\hline & Anacardium occidentale* & - & 4 \\
\hline & Celosia cristata $^{*+}$ & 7 & 27 \\
\hline & Clitoria ternatea* & - & 5 \\
\hline & Crotalaria incana & - & 10 \\
\hline & Froelichia interrupta* & - & 8 \\
\hline & Ipomoea pes-caprae* & 1 & 1 \\
\hline & Momordica charantica ${ }^{+}$ & - & 10 \\
\hline & Pavonia cancellata* & 7 & - \\
\hline Frankliniella tritici (Fitch) & Crotalaria incana & - & 1 \\
\hline \multirow{15}{*}{$\begin{array}{c}\text { Microcephalothrips abdominalis } \\
\text { (Crawford) }\end{array}$} & Allamanda cathartica* & - & 3 \\
\hline & Aspilia cearensis* & - & 3 \\
\hline & Bixa orellana* & - & 6 \\
\hline & Blainvillea rhomboidea* & - & 1 \\
\hline & Centratherum punctatum ${ }^{*+}$ & - & 12 \\
\hline & Celosia cristata* & - & 1 \\
\hline & Citrus sinensis* & - & 2 \\
\hline & Clitoria ternatea* & - & 1 \\
\hline & Crotalaria incana ${ }^{*+}$ & - & 12 \\
\hline & Helianthus annuus & - & 1 \\
\hline & Scoparia dulcis* & - & 4 \\
\hline & Setaria parviflora*+ & - & 13 \\
\hline & Stachytarpheta coccinea* & - & 4 \\
\hline & Thunbergia erecta* & - & 10 \\
\hline & Tithonia diversifolia*+ & - & 29 \\
\hline Selenothrips rubrocintus (Giard) & Anacardium occidentale $^{+}$ & - & 2 \\
\hline Caliothrips phaseoli (Hood) & Anacardium occidentale & - & 1 \\
\hline Heliothrips haemorrhoidalis (Bouché) & Bixa orellana* & & 1 \\
\hline \multirow[t]{2}{*}{ Androthrips ramachandrai (Karny) } & Anacardium occidentale* & - & 5 \\
\hline & Cyperus esculentus & - & 1 \\
\hline \multirow[t]{11}{*}{ Haplothrips gowdeyi (Franklin) } & Amaranthus deflexus & - & 1 \\
\hline & Blainvillea rhomboidea* & - & 3 \\
\hline & Celosia cristata $^{*+}$ & - & 11 \\
\hline & Chamaesyce hyssopilia & - & 1 \\
\hline & Curcubita moschata & - & 1 \\
\hline & Cyperus esculentus* & - & 4 \\
\hline & Eleusine indica* & - & 1 \\
\hline & Euphorbia hyssopifolia* & - & 1 \\
\hline & Paspalum urvillei*+ & - & 18 \\
\hline & Sida gatherensis*+ & - & 21 \\
\hline & Waltheria indica* & - & 2 \\
\hline Haplothrips trellesi (Moulton) & Waltheria indica* & - & 2 \\
\hline Treherniella sp. & Pavonia cancellata & - & 1 \\
\hline TOTAL & & 51 & 405 \\
\hline
\end{tabular}

*New records of association with plant species in Brazil; +Host-associations based on larvae collection. 


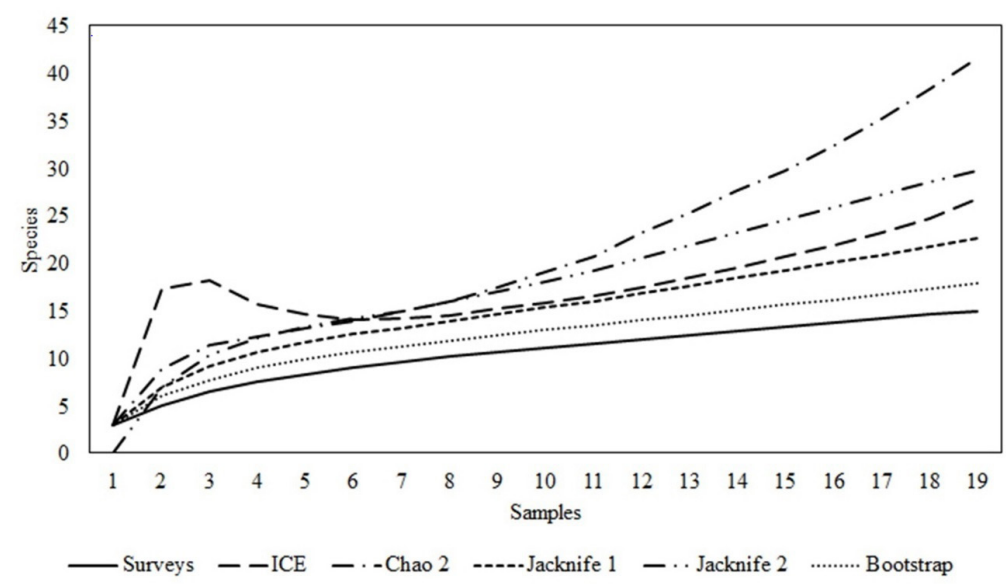

Figure 2. Species accumulation curve and richness estimators for thrips species recorded in restinga fragment in the municipality of Fortaleza, Ceará, Brazil from 2011 through 2013.

Table 3. Diversity indices of the thrips species in restinga fragment in the municipality of Fortaleza, Ceará, Brazil.

\begin{tabular}{ccc}
\hline Index & & Values \\
\hline Shannon-Wiener (H') & Sample & 1,7607 \\
& Amaranthaceae & 0.8723 \\
& Caesalpiniaceae & 0.8366 \\
Simpson (D) & Poaceae & 1.0661 \\
& Sample & 0.7769 \\
& Amaranthaceae & 0.4852 \\
& Caesalpiniaceae & 0.4019 \\
& Poaceae & 0.5378 \\
\hline
\end{tabular}

\section{Discussion}

This study established the first records of association between several thrips species and restinga plants in Brazil (Table 2). Fourteen species (seven of which, Androthrips ramachandrai, Frankliniella brevicaulis, F. gemina, F. insularis, F. tritici, Haplothrips gowdeyi, Heliothrips haemorrhoidalis, are new records) are added to the total known from state of Ceará, and the genus Treherniella is a new record in Brazil. This genus has been found on members of Poaceae in native vegetation in northern Italy (Marullo and Grazia, 2013), as well as in southern United States (Diffie et al., 2008) and in Paraguay and Argentina (ThripsWiki, 2017). Apart from Treherniella sp., all thrips species sampled in our study have been found in surveys conducted in different states of Brazil, i.e. Piauí and Maranhão (Lima and Zucchi, 2016), Rio Grande do Norte (Cavalleri et al., 2011) and Rio Grande do Sul (Pinent et al., 2005, 2006).

Most of these species are phytophagous, except for A. ramachandrai, a predator of Gynaikothrips spp. (Melo et al., 2013). The fiding 46 new associations of plant species with thrips in Brazil, along with the 13 true host associations demonstrates the importance of coastal vegetation in maintaining populations of thrips. Although the species identified are common on cultivated plants in other areas of Brazil, the failure to find other different species in the vegetation of this area is probably related to the degree of environmental alteration.

In southern Brazil, other studies in a natural area found a thrips richness in Itapuã State Park (Cavalleri, 2005; Pinent et al., 2005, 2006) that is double the level observed in our study. However, the incomplete stabilization of the species-accumulation curve indicates that a higher richness of thrips species may be found in the fragments of coastal vegetation sampled. Moreover, the collection effort (number of surveys) and specimens collected was also higher in Rio Grande do Sul. Therefore, an increase in collection efforts may well demonstrate a higher richness of thrips species in the restinga fragment sampled here.

The diversity indices calculated in our study indicate that some species are more abundant in the area, thus leaving the diversity relatively low. The Simpson Index of the complete sample was close to 1 (Table 3 ), a result of the high abundances of a few species (mainly F. insularis and Microcephalothrips abdominalis). The diversity levels within the plant families with the highest richness of thrips species were slightly higher. This can be explained by the exclusion of species with low abundance collected from other plant families (Table 2). Cavalleri (2005), in Rio Grande do Sul, found a higher diversity $(\mathrm{D}=0.211)$, as the species showed more uniform abundances.

The Shannon-Weiner index also indicated a low diversity. In Itapuã State Park, the index value was 2.19 and there were differences between the plant family with the highest thrips richness (Asteraceae) and the other families (Cavalleri, 2005). Although the collection methods used by the author are different, these comparisons give an idea of the relative diversity of these different areas.

In Brazil, very few systematic surveys of thrips in natural ecosystems have been performed, and there are no assessments of the importance of preserving natural 
areas for conservation of these insects. Especially in the northeast region of this country, where the biodiversity of these insects is little known, efforts must be made to better understand the patterns and size of thrips populations. Restinga fragments in Brazil are fragile ecosystems threatened by human settlement. The area studied here is located near to built-up areas of one of the largest cities in northeastern Brazil, and is under environmental stress. The existence of a diverse fauna of insects harbored by many plant species is an important reason to carry out efforts for their conservation.

\section{Acknowledgements}

To the Programa de Extensão Universitária (PROEX) and the Fundação Cearense de Apoio ao Desenvolvimento Científico e Tecnológico (FUNCAP) for the research scholarships granted; to Gessiane da Silva Viana for the help in the sampling; and to Dr. Laurence A. Mound (ANIC/CSIRO, Australia) for his help in the identification of some thrips.

\section{References}

BRANDÃO, R.L., 2003. Diagnóstico geoambiental e os principais problemas de ocupação do meio físico da região Metropolitana de Fortaleza. Fortaleza: CPRM. Projeto SINFLOR.

BRIDSON, D. and FORMAN, L., 1998. The herbarium handbook. 3rd ed. London: Royal Botanical Gardens, 334 p.

BRITO, A.E.R.M., MADEIRA, Z.R., COSTA, F.A.P., NUNES, E.P., MATIAS, L.Q. and SILVA, F.H.M., 2006. Vegetação costeira do Nordeste semi-árido: guia ilustrado. Fortaleza: Edições UFC, 274 p.

CAVALLERI, A., 2005. Comunidades de tripes (Insecta: Thysanoptera) em flores e ramos, com ênfase em Asteraceae, no parque estadual de Itapuã, Viamão, $R S$. Porto Alegre: Universidade Federal do Rio Grande do Sul, 182 p. Dissertação de Mestrado em Biologia Animal.

CAVALLERI, A., LIMA, M.G.A., MELO, F.S. and MENDONÇA JUNIOR, M.S., 2011. New records of thrips (Thysanoptera) species in Brazil. Neotropical Entomology, vol. 40, no. 5, pp. 628-630. http://dx.doi.org/10.1590/S1519-566X2011000500019. PMid:22068954.

COLWELL, R.K., 2013 [viewed 30 January 2015]. EstimateS, version 9.1: statistical estimation of species richness and shared species from samples: software and user's guide [software]. Available from: http://viceroy.eeb.uconn.edu/estimates

COSTA, E.M., LIMA, M.G.A., SALES JUNIOR, R., CAVALLERI, A. and ARAÚJO, E.L., 2015. Tripes coletados na cultura da melancia no semiárido do Rio Grande do Norte, Brasil. Ciência Rural, vol. 45, no. 4, pp. 575-577. http://dx.doi.org/10.1590/01038478cr20131322.

DIFFIE, S., EDWARDS, G.B. and MOUND, L.A., 2008. Thysanoptera of Southeastern U.S.A.: a checklist for Florida and Georgia. Zootaxa, vol. 1787, pp. 45-62.

ESTEVES, F.A. and LACERDA, L.D., 2000. Ecologia de restingas e lagoas costeiras. 1st ed. Macaé: Computer \& Publish Editoração Gráfica, 446 p.
FLINTE, V., ARAÚJO, C.O., MACEDO, M.V. and MONTEIRO, R.F., 2006. Insetos fitófagos associados ao murici da praia, Byrsonima sericea (Malpighiaceae), na Restinga de Jurubatiba (RJ). Revista Brasileira de Entomologia, vol. 50, no. 4, pp. 512-523. http://dx.doi.org/10.1590/S0085-56262006000400012.

GOSTINSKI, L.F., CARVALHO, G.C.A., RÊGO, M.M.C. and ALBUQUERQUE, P.M.C., 2016. Species richness and activity pattern of bees (Hymenoptera, Apidae) in the restinga area of Lençóis Maranhenses National Park, Barreirinhas, Maranhão, Brazil. Revista Brasileira de Entomologia, vol. 60, no. 4, pp. 319-327. http://dx.doi.org/10.1016/j.rbe.2016.08.004.

GOTELLI, N. and COLWELL, R.K., 2001. Quantifying biodiversity: procedures and pitfalls in the measurement and comparison of species richness. Ecology Letters, vol. 4, no. 4, pp. 379-391. http:// dx.doi.org/10.1046/j.1461-0248.2001.00230.x.

INSTITUTO BRASILEIRO DE GEOGRAFIA E ESTATÍSTICA - IBGE, 2012. Manual técnico da vegetação brasileira: sistema fitogeográfico: inventário das formações florestais e campestres: técnicas e manejo de coleções botânicas: procedimentos para mapeamentos. 2nd ed. Brasília: Coordenação de Recursos naturais e Estudos Ambientais, IBGE.

LEWIS, T., 1973. Thrips: their biology, ecology, and economic importance. London: Academic Press, 349 p.

LEWIS, T., 1997. Pest thrips in perspective. In: T. LEWIS, ed. Thrips as crop pests. Wallingford: CAB International, pp. 1-13.

LIMA, E.F.B., 2017 [viewed 16 February 2017] Thysanoptera [online]. Rio de Janeiro: Jardim Botânico do Rio de Janeiro. Available from: http://fauna.jbrj.gov.br/fauna/faunadobrasil/316

LIMA, E.F.B. and ZUCCHI, R.A., 2016. Thrips on fabaceous plants and weeds in an ecotone in northeastern Brazil. Ciência Rural, vol. 46, no. 3, pp. 393-398. http://dx.doi.org/10.1590/0103$8478 \mathrm{cr} 20150613$.

LIMA, E.F.B., FONTES, L.S., PINENT, S.M.J., REIS, A.S., FREIRE FILHO, F.R. and LOPES, A.C.A., 2013a. Thrips species (Insecta: Thysanoptera) associated to Cowpea in Piauí, Brazil. Biota Neotropica, vol. 13, no. 1, pp. 383-386. http://dx.doi. org/10.1590/S1676-06032013000100043.

LIMA, E.F.B., MONTEIRO, R.C. and ZUCCHI, R.A., 2013b. Thrips species (Insecta: Thysanoptera) associated to Fabaceae of agricultural importance in Cerrado and Amazon-Caatinga ecotone from Brazilian Mid-North. Biota Neotropica, vol. 13, no. 2, pp. 283-289. http://dx.doi.org/10.1590/S1676-06032013000200027.

LIMA, M.G.A., CAVALLERI, A., ARAÚJO, E.L., SOUSA, M.D.F. and PINENT, S.M.J., 2011. Espécies de tripes encontradas nas culturas de abobrinha, cebola e tomate em Carnaubal - CE. 1st ed. Fortaleza: EdUECE, 28 p.

MARULLO, R. and GRAZIA, A., 2013. Territorial distribution, classification and relationships amongst Italian Thysanoptera. Bulletin of Insectology, vol. 66, no. 1, pp. 127-134.

MELO, F.S., CAVALLERI, A. and MENDONÇA JÚNIOR, M.S., 2013. Predation of Gynaikothrips uzeli (Thysanoptera: Phlaeothripidae) by Androthrips ramachandrai (Thysanoptera: Phlaeothripidae). The Florida Entomologist, vol. 96, no. 3, pp. 859-863. http://dx.doi.org/10.1653/024.096.0320.

MONTEIRO, R.C. and LIMA, E.F.B. 2011 [viewed 16 February 2017]. Thysanoptera of Brazil. Piracicaba: USP. Available from: http://www.lea.esalq.usp.br/thysanoptera/ 
MONTEIRO, R.C. and MOUND, L.A., 2012. Thysanoptera. In: J. A. RAFAEL, G. A. R. MELO, C. J. B. CARVALHO, S. A. CASARAI and R. CONSTANTINO, eds. Insetos do Brasil: diversidade e taxonomia. Ribeirão Preto: Holos, pp. 407-422.

MONTEIRO, R.C., 2002. The Thysanoptera fauna of Brazil. In: R. MARULLO and L. A. MOUND, eds. Thrips and Tospoviruses. Canberra: Australian National Insect Collection, pp. 325-340.

MONTEIRO, R.F., MACEDO, M.V., NASCIMENTO, M.S. and CURY, R.S.F., 2007. Composição, abundância e notas sobre a ecologia de espécies de larvas de lepidópteros associadas a cinco espécies de plantas hospedeiras no Parque Nacional da Restinga de Jurubatiba, RJ. Revista Brasileira de Entomologia, vol. 51, no. 4, pp. 476-483. http://dx.doi.org/10.1590/S0085-56262007000400012.

MORO, M.F., CASTRO, A.S.F. and ARAÚJO, F.S., 2011. Composição florística e estrutura de um fragmento de vegetação savânica sobre os tabuleiros pré-litorâneos na zona urbana de Fortaleza, Ceará. Rodriguésia, vol. 62, no. 2, pp. 407-423. http:// dx.doi.org/10.1590/2175-7860201162214.

MOUND, L.A. and MARULLO, R., 1996. The thrips of Central and South America: an introduction (insecta: Thysanoptera). Gainesville: Associated Publishers, 488 p. Memoirs on Entomology, no. 6.

MOUND, L.A., 2013. Homologies and host-plant specificity: recurrent problems in the study of thrips. The Florida Entomologist, vol. 96, no. 2, pp. 318-322. http://dx.doi.org/10.1653/024.096.0250.

OLIVEIRA, M.D., BARBOSA, F.R., CORTEZ, J.A. and SILVEIRA, L.C.P., 2011. Espécies de Frankliniella (Thysanoptera,
Thripidae): novos registros em mangueira (Mangifera indica) no Brasil. Ciência Rural, vol. 41, no. 10, pp. 1709-1711. http:// dx.doi.org/10.1590/S0103-84782011005000131.

PINENT, S.M., ROMANOWSKI, H.P., REDAELLI, L.R. and CAVALLERI, A., 2006. Species composition and structure of Thysanoptera communities in different microhabitats at the Parque Estadual de Itapuã, Viamão, RS. Brazilian Journal of Biology = Revista Brasileira de Biologia, vol. 66, no. 3, pp. 765-779. http:// dx.doi.org/10.1590/S1519-69842006000500002. PMid:17119824.

PINENT, S.M.J., ROMANOWSKI, H.P., REDAELLI, L.R. and CAVALLERI, A., 2005. Thysanoptera: Plantas visitadas e hospedeiras no Parque Estadual de Itapuã, Viamão, RS, Brasil. Iheringia: Série Zoologia, vol. 95, no. 1, pp. 9-16. http://dx.doi. org/10.1590/S0073-47212005000100002.

RODRIGUES, W.C., 2015 [viewed 16 February 2017]. DivEs: Diversidade de Espécies v3.0 [software]. Available from: http:// dives.ebras.bio.br/

SILVEIRA, V.R., MONTEIRO, R.F. and MACEDO, M.V., 2008. Larvas de insetos associadas a Clusia hilariana Schltdl. (Clusiaceae) na Restinga de Jurubatiba, RJ, Brasil. Revista Brasileira de Entomologia, vol. 52, no. 1, pp. 57-61. http://dx.doi. org/10.1590/S0085-56262008000100010.

THRIPSWIKI, 2017 [viewed 16 February 2017]. Available from: http://thrips.info 